\title{
STRATEGI BERBICARA MAHASISWA KETIKA MENGALAMI KESULITAN DALAM AKTIVITAS BERBICARA
}

\author{
Rahmat Nasrullah ${ }^{1}$; Syarif Amin ${ }^{2}$ \\ ${ }^{12}$ Program Studi Pendidikan Bahasa Inggris, Fakultas Keguruan dan Ilmu Pendidikan, \\ Universitas Muhammadiyah Kendari \\ e-mail: *rahmat.nasrullah@umkendari.ac.id, syarifumkendari@gmail.com
}

\begin{abstract}
ABSTRAK: Kesulitan bercakap merupakan salah satu isu yang sering ditemukan pada kelas berbicara (Speaking) dan memiliki efek yang dapat mempengaruhi minat belajar mahasiswa. Penelitian ini bertujuan untuk mengetahui strategi berkomunikasi mahasiswa ketika mengalami kesulitan bercakap dan faktor apa saja yang menyebabkan kesulitan tersebut. Pendekatan deskriptif kualitatif digunakan untuk memahami fenomena tersebut. Angket, dan wawancara digunakan untuk mengumpulkan data. Hasil penelitian ini menunjukkan untuk mengatasi kesulitan-kesulitan seperti dalam hal kesulitan kosa kata, struktur kalimat, pengucapan dan kurangnya kepercayaan diri. Mahasiswa menggunakan beberapa strategi komunikasi dalam kegiatan berbicara. Strategi-strategi tersebut adalah penaksiran, perkiraan, alih kode, terjemahan literal, dan permohonan bantuan, dan menggunakan cara non-linguistik.
\end{abstract}

Kata Kunci Kesulitan bercakap; strategi komunikasi; deskriptif kualitatif

Abstract: Speaking difficulty is one of the issues that is frequently found in speaking classes and has an effect that can affect students interest in learning. This study aims to determine the communication strategies of students when having difficulty speaking and what factors are causing these difficulties. A qualitative descriptive approach was used to understand the phenomenon. Questionnaires, and interviews were employed to collect data. The results of this study indicated that to students faced commonly difficulties such as vocabulary difficulties, sentence structure, pronunciation and lack of confidence. To overcome the difficulties, Students applied several communication strategies in speaking activities. These strategies were assessment, estimation, code switching, literal translation, and requests for help, and using non-linguistic methods.

Keywords: speaking difficulties; communication strategies; qualitative.

\section{PENDAHULUAN}

Fokus pengajaran berbicara adalah untuk meningkatkan produksi lisan para siswa. Selain itu, Littlewood (1981) berpendapat bahwa beberapa guru menggunakan bahasa pertama untuk manajemen kelas. Namun demikian, ini bisa menjadi faktor lain yang berkontribusi terhadap masalah kesulitan berbicara. Oleh karena itu, guru bahasa Inggris harus berusaha menciptakan suasana yang harmonis dalam kelas bahasa Inggris lisan sehingga siswa memiliki keinginan dan minat dalam berbicara. Dalam pembelajaran bahasa, ada empat kondisi yang harus ada yaitu eksposur, kesempatan untuk menggunakan bahasa, motivasi, dan pengajaran. Selain itu, dengan menggunakan permainan, permainan peran, obrolan ringan, diskusi bebas dan kegiatan drama 
memberi kesempatan kepada siswa dan meningkatkan kepercayaan diri mereka untuk berbicara.

Kesulitan berbicara adalah sesuatu yang membuat berbicara sulit dilakukan oleh para siswa. Menurut Jordan (1997), masalah yang paling sering dijumpai siswa adalah ketidakmampuan untuk mengekspresikan diri secara memadai dalam bahasa lisan. Artinya siswa harus membiasakan diri dalam komunikasi lisan agar bisa berkomunikasi dengan bahasa Inggris. Selain itu, produksi bahasa lisan sering dianggap sebagai salah satu aspek pembelajaran bahasa yang paling sulit karena melibatkan banyak komponen seperti tata bahasa, strategi, sosiolinguistik dan wacana. Selain itu, Thornbury (2005) mengatakan bahwa ada beberapa kondisi yang membuat mudah berbicara atau sulit. Kondisi tersebut meliputi tiga faktor yaitu faktor kognitif, faktor afektif dan faktor kinerja. Kemudian, kesulitan berbicara juga dipengaruhi oleh beberapa faktor, antara lain faktor linguistik. Faktor linguistik mengacu pada unsur bahasa itu sendiri, yang meliputi tatabahasa, kosa kata, dan sound system atau pengucapan. Oleh karena itu, siswa harus bisa mengetahui faktor-faktor yang membuat sulit berbicara sehingga bisa menemukan solusi untuk mengatasi hambatan tersebut.

Selanjutnya, untuk mengatasi masalah berbicara siswa dapat menerapkan beberapa strategi komunikasi. Strategi yang bisa mereka terapkan saat menghadapi masalah dalam berbicara seperti, circumlocution, gestures, parafrase atau meminta klarifikasi. Strategi ini sangat penting bagi siswa karena ketika menghadapi kesulitan mereka dapat memanggil strategi komunikasi ini. Selain itu, tujuan dari strategi ini adalah untuk menjaga atau menghindari gangguan arus komunikasi. Seperti yang dikatakan di Bialystok, (1990:3), strategi komunikasi adalah teknik mengatasi kesulitan dalam berkomunikasi secara tidak sempurna mengenal bahasa kedua atau bahasa asing. Oleh karena itu, guru bahasa Inggris harus mampu mengembangkan kompetensi komunikatif agar siswa terbiasa dengan strategi komunikasi. Dengan mengembangkan kompetensi komunikatif, siswa dapat berinteraksi lebih berhasil dalam percakapan.

Berkenaan dengan permasalahan di atas, peneliti melakukan penelitian tentang strategi siswa dalam menyelesaikan kesulitan berbicara siswa bahasa Inggris di Universitas Muhammadiyah Kendari. Hal ini bertujuan untuk mengungkapkan jenis kesulitan berbicara yang dihadapi oleh siswa dan untuk mengidentifikasi strategi yang mereka gunakan untuk memecahkan kesulitan.

\section{METODE PENELITIAN}

Metode survey dengan skala likert digunkan dalam penelitian ini, yaitu dengan menyebar angket dan wawancara. Metode likert scale survey adalah metode penelitian kuantitatif untuk mendapatkan data dari sekelompok manusia dengan pendekatan setuju/tidak setuju, puas/tidak puas, dan sebagainya tentang sikap, opini, tingkah laku, atau karakteristik dari mahasiswa asing sebagai partisipan dari penelitian ini. dalam jenis penelitian ini peneliti mengumpulkan data secara kuantitatif, data tersebut berupa; angket dan wawancara dan dikutakan oleh data observasi, dan data yang dianalisis secara statistik untuk menunjukan trend dari respon yang diberikan oleh populasi sasaran tentang fenomena yang dibahas. (Creswell, 2012). Data yang didapat dari angket tersebut disajikan dalam bentuk diagram untuk mengetahui berbagai macam kesulitan dan strategi berkomunikasi mahasiswa ketika kegiatan berbicara. 


\section{HASIL PENELITIAN DAN PEMBAHASAN}

Berdasarkan masalah penelitian yang telah dirumuskan, hasil dari penelitian ini menunjukkan bahwa mahasiswa menggunakan beberapa strategi berbicara ketika menghadapi beberapa masalah dalam berbicara. Masalah yang hal ini dapat dilihat dari gambaran diagram berikut:

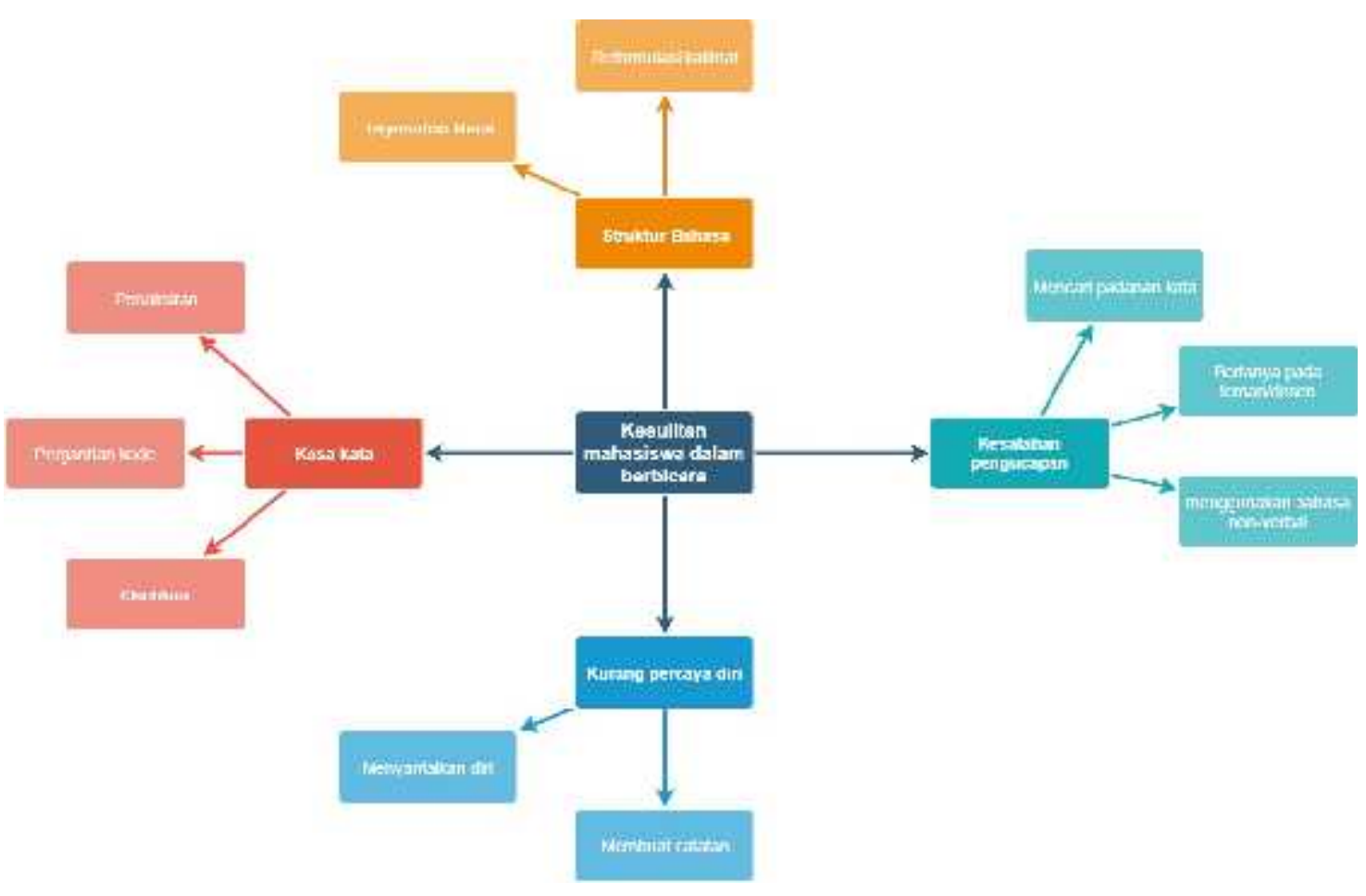

\section{Gambar 1. Stategi Berbicara Ketika Menghadapi Beberapa Masalah Dalam Berbicara}

Untuk mengatasi kesulitan-kesulitan di atas, berikut adalah beberapa strategi yang digunakan oleh siswa ketika berbicara di kelas berbicara yaitu: penaksiran, klarifikasi, alih kode, terjemahan literal, dan memohon bantuan, menggunakan filler,reformulasi kalimat menggunakan bahasa non-verbal.

Salah satu strategi yang digunakan oleh siswa dalam menyelesaikan kesulitan berbicara mereka adalah strategi penaksiran/ circumlocution. Strategi ini digunakan ketika siswa kehilangan atau melupakan kata dan mereka tidak tahu bagaimana mengatakan kata itu dalam bahasa Inggris selama melakukan diskusi atau kegiatan berbicara. Circumlocution juga digunakan ketika siswa tidak mungkin menggunakan kamus saat berbicara. Masalah ini muncul karena kosa kata yang terbatas itu sendiri. Strategi ini digunakan dengan mengganti kalimat yang tidak dikenal atau dilupakan dengan sinonim atau kalimat deskriptif. Dalam Canale dan Swain (1980), sunat dianggap sebagai strategi pencapaian yang paling penting dan komponen utama dari kompetensi 
strategis. Ini karena dapat membantu siswa untuk menghindari penggunaan bahasa pertama mereka selama berbicara di kelas.

Selain itu, strategi selanjutnya yang digunakan oleh siswa ketika menghadapi kesulitan berbicara adalah perkiraan/approximant. Strategi ini digunakan oleh siswa ketika mereka tidak dapat menemukan yang benar ketika berbicara. Perkiraan juga merupakan strategi yang berguna dan diinginkan karena mendorong siswa untuk menggunakan istilah yang mengekspresikan makna kata target sedekat mungkin. Menurut Tarone (1977) aproksimasi adalah strategi menggunakan item atau struktur kosa kata bahasa target tunggal, yang pembelajar tahu adalah tidak benar, tetapi yang berbagi fitur semantik yang sama dengan item yang diinginkan untuk memuaskan penutur Selain itu, strategi ini adalah digunakan ketika siswa kehilangan kata dan mereka tidak dapat kata sinonim baik oleh karena itu mereka mencoba untuk menemukan kata lain yang memiliki arti dekat. Penelitian ini memiliki kemiripan dengan penelitian yuliyastutik (2007) di mana ia menemukan bahwa siswa menggunakan menggunakan pendekatan dalam menyelesaikan kesulitan berbicara.

Selanjutnya, alih kode juga merupakan strategi yang digunakan oleh siswa ketika mereka kehilangan ide atau kata. Strategi ini digunakan dengan menggabungkan dengan Bahasa dan Bahasa Inggris saat berbicara. Akibatnya, alih kode adalah sebagai strategi komunikasi untuk bilingual (Blom \& Gumperz, 1972; Genesee et al., 2004). Siswa menggunakan strategi ini ketika mereka tidak dapat mengungkapkan kata itu dalam bahasa Inggris. Di sisi lain, siswa menggunakan strategi ini ketika kemudian tidak dapat menggambarkan atau menemukan kata lain ketika berbicara. Selain itu, strategi ini tidak sering digunakan oleh siswa hanya dalam beberapa kondisi di mana jika mereka benarbenar tidak tahu bagaimana mengatakan kata itu dalam bahasa Inggris. Dengan demikian, strategi ini digunakan untuk menyelesaikan komunikasi dan mengatasi kurangnya elemen linguistik.

Kemudian, terjemahan literal digunakan ketika siswa mengalami kesulitan untuk mengubah ide mereka dalam bahasa Inggris. Di mana, siswa pertama-tama memikirkan ide mereka dan kemudian menerjemahkannya dalam bahasa Inggris ketika berbicara seperti yang dikatakan oleh Dornyei dan scott (1997) terjemahan literal adalah strategi yang menerjemahkan secara harfiah item leksikal, idiom, kata majemuk atau struktur dari bahasa asli ke bahasa asing. Ini adalah kesulitan yang dihadapi oleh siswa ketika mereka tidak tahu bagaimana struktur kalimat mereka. Dalam kesamaan, penelitian ini berkaitan dengan penelitian yuliyatutik (2007) di mana ia menemukan bahwa siswa beralih ke bahasa asli ketika mereka mengalami kesulitan dalam berbicara. Oleh karena itu, siswa menggunakan terjemahan literal karena strategi ini dapat membantu siswa untuk terus membagikan ide mereka ketika mengalami kesulitan berbicara terutama untuk struktur tata bahasa.

Selain menggunakan filler, siswa juga menggunakan pengulangan diri ketika berbicara di kelas dalam mengisi waktu kosong atau jeda. Pengulangan diri adalah strategi pengulangan kata atau serangkaian kata segera setelah mereka diucapkan (Dornyei dan Scott, 1998). Strategi ini memiliki fungsi yang sama dengan menggunakan pengisi yaitu untuk mengambil waktu berpikir ketika kehilangan kata saat berbicara. Berdasarkan hasil pengamatan, beberapa siswa cenderung menggunakan pengulangan diri daripada menggunakan pengisi ketika mereka mengisi kemudian waktu kosong 
untuk memikirkan apa yang ingin mereka katakan. Selain itu, repletion diri juga mendapat skor tinggi dari kuesioner di mana mendapat $82 \%$. Ini berarti bahwa siswa juga cenderung menggunakan strategi ini ketika mengalami kesulitan berbicara terutama untuk mengisi waktu kosong ketika mereka kehilangan kata atau melupakan apa yang ingin mereka katakan.

Strategi lain yang digunakan oleh siswa dalam memecahkan kesulitan berbicara adalah penggunaan bahasa non-verbal. Penggunaan cara nonlinguistik adalah bahwa seorang pelajar menggunakan sumber daya non-linguistik seperti pantomim, gerakan, ekspresi wajah, dan peniruan suara untuk membantunya mengekspresikan makna (Dornyei, 1995). Ini adalah strategi nonverbal yang digunakan ketika siswa mengalami kesulitan untuk mengekspresikan ide mereka. Akibatnya, untuk mengekspresikan ide mereka, siswa menggunakan strategi ini untuk memastikan ide mereka ketika berbicara. Strategi ini juga digunakan oleh siswa ketika mereka merasa gugup atau kurang percaya diri ketika berbicara dengan mencoba bersikap santai, tenang dan menikmati saat berbicara. Selain itu, siswa menggunakan bahasa tubuh dan ekspresi wajah untuk menekankan apa yang mereka maksud dengan tepat untuk mendukung aktivitas berbicara mereka.

Meminta pengulangan adalah strategi yang digunakan oleh siswa ketika berbicara dalam kelompok atau berpasangan. Di mana, dalam aktivitas berbicara ini semua kelas menerapkan aktivitas itu ketika belajar berbicara. Ketika berbicara berpasangan atau kelompok, siswa mendapat kesulitan seperti mereka tidak mengerti maksudnya. Dalam mengatasi kesulitan ini siswa meminta pengulangan dari lawan bicara dengan mengatakan maaf, maafkan saya dan bisakah Anda mengulanginya. Dari wawancara, sebagian besar siswa menggunakan strategi ini ketika mereka tidak mengerti atau mendapatkan poin dengan jelas. Ini berarti siswa meminta pengulangan sehingga mereka bisa mengerti saat berbicara. Oleh karena itu, strategi ini sangat berguna bagi siswa ketika mereka berbicara berpasangan atau kelompok untuk mempertahankan percakapan ketika berbicara. Meminta pengulangan mendapatkan skor tertinggi dari kuesioner di mana itu adalah 91, 1\%. Ini berarti sebagian besar siswa menggunakan strategi ini ketika mereka tidak mendapatkan poin saat melakukan percakapan.

Meminta klarifikasi juga merupakan salah satu strategi yang digunakan siswa ketika menghadapi kesulitan berbicara dalam percakapan interaksional. Strategi ini digunakan ketika siswa tidak yakin apa yang dikatakan lawan bicara. Karena itu, untuk memperjelas maksudnya siswa meminta klarifikasi dari teman-teman mereka. Ini dibuktikan dari pengamatan di kelas, siswa meminta klarifikasi ketika mereka tidak mengerti apa yang dikatakan lawan bicara dengan mengajukan pertanyaan. Akibatnya, teman bicara mereka menjelaskannya sehingga mereka bisa mengerti maksudnya. Penelitian ini mirip dengan penelitian Lopez (2011) di mana ia menemukan bahwa siswa cenderung meminta pesan dalam berbicara. klarifikasi Oleh karena itu, strategi ini sangat membantu siswa karena dapat membantu mereka membuat pesan lebih jelas saat melakukan percakapan.

\section{KESIMPULAN}

Untuk mengatasi kesulitan-kesulitan seperti dalam hal kesulitan kosa kata, struktur kalimat, pengucapan dan kurangnya kepercayaan diri. Mahasiswa 
menggunakan beberapa strategi komunikasi dalam kegiatan berbicara. Strategi-strategi tersebut adalah penaksiran, perkiraan, alih kode, terjemahan literal, dan permohonan bantuan, dan menggunakan cara non-linguistik. Strategi-strategi diatas digunakan oleh mahasiswa secara berulang sesuai kesulitan yang mereka hadapi ketika berbicara. Dari kesimpulan di atas tentang kesulitan dan strategi berkomunikasi ketika kegiatan berbicara di dalam kelas input bahasa dalam hal ini kosa kata dan bahasa fungsional diberikan contoh yang lebih banyak kepada siswa agar mendukung mereka dalam kegiatan berbicara

\section{UCAPAN TERIMA KASIH}

Penulis mengucapkan terima kasih kepada Lembaga Penelitian dan Pengabdian Kepada Masyarakat (LPPM), Universitas Muhammadiyah Kendari yang telah memberikan dukungan finansial dalam penelitian ini.

\section{DAFTAR PUSTAKA}

Bialystok, E.1990. Communication Strategies: A Psychological Analysis of Second Language Use M]. London: Blackwell.

Brown, H. D. 1994. Principle of language learning and teaching. (3 ${ }^{\text {rd }}$ ed.). England: Pearson Education Limited.

Brown, H. D. 2001. Teaching by principles: An interactive approach to language pedagogy. Beijing: Language Teaching and Research Press,

Celce-Murcia. M. 2001. Teaching English as a Second or Foreign Language (3rd ed). USA: Heinle\&Heinle.

Chaney, A.L., and T.L. Burk. 1998. Teaching Oral Communication in Grades K-8. Boston: Allyn\&Bacon.

Dornyei, Z. 1995. On the teachability of communication strategies. TESOL Quarterly, 29, 55-85.

Dornyei, Z., \& Scott M., L. 1997. Communication strategies in a second language: Definitions and taxonomies. Language Learning.47, 173-210.

Harmer, J. 2007. The Practice of English Language Teaching Fourth Edition. Cambridge: Pearson Longman.

Miles, M.B, and Huberman, A.M. 1994. Qualitative Data Analysis, 2nd Ed., p. 10-12. Newbury Park, CA: Sage.

Thornbury, S., 2007. How to Teach Speaking. Harlow: Pearson Education Limited.

Ur, P. 1996. A course in language teaching.Cambridge: Cambridge University Press.

Yuliyastutik. 2007. Students' Strategies to Overcome Speaking Problems in the Conversation Class as an Intra-curricular Program at SMA Negeri 8 Malang. Published Thesis. 